\title{
The Literary Witness: Labyrinths in Pliny, Virgil, and Ovid
}

Dicamus et labyrinthos, vel portentosissimum humani inpendii opus, sed non, ut existimari potest, falsum.

We must speak also of the labyrinths, the most astonishing work of human riches, but not, as one might think, fictitious.

Pliny, Natural History 36.19 .84

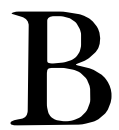

Y THE time of Juvenal (ca. 6o-131 A.D.), "that thingummy in the Labyrinth" and "the flying carpenter" who built it were the stock in trade of hack poets, and references to the labyrinth and its associated myth abound in classical literature. Of the many writers who treated the subject, three are particularly important, not merely because of their stature in their own age but also because they defined the labyrinth for early Christian and medieval writers, establishing a rich storehouse of labyrinthine characteristics and associations and laying the groundwork for the literal and metaphorical mazes of later literature. These three classical authors are Virgil (70-19 B.c.), Ovid (43 B.C. -17 A.D.), and Pliny the Elder (23-79 A.D.), whom I discuss in conjunction with other historical-geographical writers. ${ }^{1}$ Each in his own way

1. For Juvenal, see Satire 1.53-54 (the Latin reads, "aut mugitum labyrinthi et mare percussum puero fabrumque volantem"). I quote Peter Green's racy translation in the Sixteen Satires (Harmondsworth: Penguin, 1967), p. 67; see also Juvenal and Persius, ed. G. G. Ramsay, LCL (London: Heinemann, 1940). For the three major texts, I follow Pliny, Natural History, trans. D. E. Eichholz, LCL, vol. o (London: Heinemann, 1962), 36.19; Virgil, The Aeneid, trans. H. Rushton Fairclough, LCL, 2 vols. (Cambridge: Harvard University Press, 1916; rev. ed. 1935), 5.553-603 and 6.1-105; Ovid, Metamorphoses, trans. Frank Justus Miller, LCL (Cambridge: Harvard University Press, 1956), 8.1-262.

Other historical-geographical writers include Herodotus, The History, trans. David Grene (Chicago: University of Chicago Press, 1987), 2.148; Diodorus of Sicily, Bibliotheca historica, trans. C. H. Oldf ather, LCL, 10 vols. (Cambridge: Harvard University Press, 1960), 1.66; Strabo (called "The Geographer" in the Middle Ages), The Geography, trans. Horace Leonard Jones, LCL, 8 vols. (Cambridge: Harvard University Press, 1959), 17.1.37; and 
expressed one major paradox inherent in the labyrinth image: its status as simultaneously a great and complex work of art and a frightening and confusing place of interminable wandering - the labyrinth as order and as chaos, depending on the observer's knowledge and perspective. But there is an important distinction among these seminal describers of the labyrinth: Pliny and other historical-geographical writers were interested chiefly in the facts of the ancient labyrinths, their status as buildings, their design and purpose, the skill of their architects; Ovid, ingenious author of entertaining fiction, was concerned chiefly with the myth (and to some extent the morality) of the Cretan maze, with the labyrinth's story rather than its structure; but Virgil, grand predecessor of both, writing fiction freighted with quasi-historical authority, was fascinated with story and structure, the path through the maze as well as its elaborate pattern. In this chapter we will see some of the literary effects of these various preoccupations.

Later writers, like their classical prototypes, also tend to emphasize either fact or fiction, building or legend, in their variations on the theme of the labyrinth. Writers emphasizing objective fact of ten follow Pliny by stressing magnificence of design, the maze as artistic building; those more concerned with myth or fiction follow Ovid and typically explore the subjective experience of being within a maze and suffering its intellectual confusions and moral delusions; and some rare authors, such as Dante and Chaucer, share Virgil's comprehensive vision and arrive at the richest developments of the idea of the labyrinth by blending labyrinthine fact and fiction, structure and story, objective pattern and subjective path. Metaphorical uses of the labyrinth to connote brilliant artistry of ten depend ultimately on the historical-geographical tradition of the labyrinth as a real building of dazzling complexity, viewed from a privileged perspective or with the sophistication of an architectural connoisseur, whereas metaphors involving confusion, error, and entrapment of ten rely more on the fictional-mythical tradition and an identification with those trapped in the maze.

The myth of the many-pathed ("multicursal") Cretan labyrinth existed in some form as early as Homer, who describes on Achilles' great shield the dancing-floor that Daedalus made in Crete for Ariadne, a passage of ten interpreted as alluding to the labyrinth. ${ }^{2}$ The labyrinth design in

Pomponius Mela, De chorographia, ed. Carl Frick (Stuttgart: B. G. Teubner, 1968), 1.8.9 (56).

2. Iliad 18.590-592. Kern cites this passage as evidence that the first labyrinth was an intricate dance. See also Lillian B. Lawler, The Dance in Ancient Greece (Middletown: Wesleyan University Press, 1964), pp. 44-46, and James Miller, Measures of Wisdom: The Cosmic Dance in Classical and Christian Antiquity (Toronto: University of Toronto Press, 1986), pp. 24-25. 


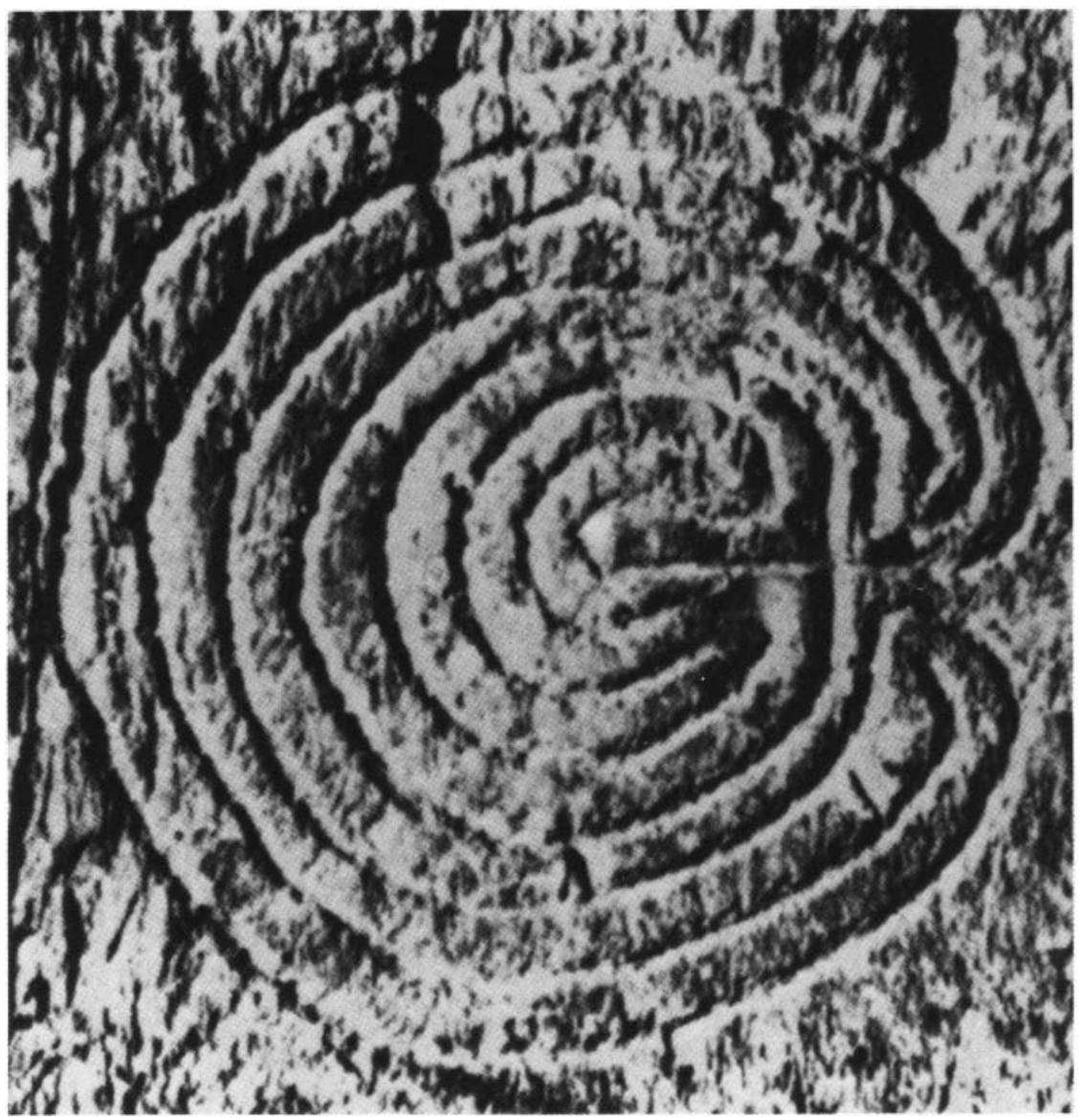

1. Typical Cretan-style labyrinth design. One of two labyrinths carved in stone at Rocky Valley, near Tintagel, Cornwall (ca. 1800-1400 B.c.). Photograph courtesy of Edwin H. Gardner.

the visual arts - a square or circular diagram in which a single unbranched ("unicursal") circuitous route leads inevitably, if at great length, to the center -is older still, dating back to prehistoric times (see plate 1). ${ }^{3}$ Since this book must recognize some limits, I focus on the classical works most influential in early Christian and medieval times. Thus the origins and early transmission of myth and visual image alike-subjects of speculation rather than of knowledge-lie beyond my scope, and I regretfully exclude some classical treatments of the story as

3. See Kern, chaps. 1 and 4 . 
well. ${ }^{4}$ The conflict between literary and visual models of the labyrinth, to which I have just alluded, is touched on here and there in this chapter when the subject naturally arises from the texts; it becomes the major theme of Chapter 2.

Here I address the most significant classical literary witnesses, and because labyrinthine "facts" in some sense underlie poetic fiction, I begin with the historical-geographical tradition, which describes not only the Cretan maze familiar to modern readers but also other ancient labyrinths, telling us what they looked like, how and why they were built, and what they were used for. This tradition, highlighting labyrinthine artistry, is at least as old as Herodotus (fifth century B.c.) and encompasses a number of authorities. Although Pliny's description of ancient labyrinths is comparatively late, among historical-geographical accounts it is fullest and best-known in the Middle Ages, and thus it provides a good framework for further discussion. ${ }^{5}$

Pliny considers the four labyrinths of the ancient world in the context of great architectural achievements, among which the labyrinths (in Egypt, Crete, Lemnos, and Etruria) were the most extraordinary (portentosissimi), incredibly complex in construction and inordinately expensive to build; the Etruscan labyrinth, the tomb of Lars Porsenna, in particular was an "insane folly" that "exhausted . . the resources of a kingdom." Pliny assures his readers (perhaps those skeptical of the Cretan myth?) that these magnificent creations are "by no means fictitious." His emphasis on the labyrinths' architectural splendor is anticipated by Herodotus, who visited the Egyptian maze and found it even more splendid than the pyramids: "If one were to collect together all the buildings of the Greeks and their most striking works of architecture, they would all clearly be shown to have cost less labor and money than this labyrinth." Diodorus Siculus (fl. 49 B.c.) concurs, stressing the magnificence and magnitude of the Egyptian maze, whose artistic carvings, ceiling paintings, relics, and murals would have made it insurpassable in execution, had it ever been finished.

4. For classical sources and variants of the myth, see A. S. Hollis's edition of Metamorphoses Book VIII (Oxford: Clarendon Press, 1970), notes on 152-259; Howard Jacobson, Ovid's Heroides (Princeton: Princeton University Press, 1974), pp. 213-216; Plutarch's Theseus, which preserves material from now-lost sources; and Johannes Meursius, Creta, Cyprus, Rhodus (Amsterdam: Abraham Wolfgang, 1675), pp. 67-70. Robert Graves, The Greek Myths, 2 vols., rev. ed. (Harmondsworth: Penguin, 1960), sections 88, 9o, 91, 92, 95, $96,97,98$, is provocative, but Graves's interpretations (as opposed to retellings) must be taken with a large grain of salt. So too with Raymond J. Clark, Catabasis, chap. 5 .

The most intriguing classical version of the myth-omitted here as irrelevant to the medieval tradition-is Catullus's Carmen 64:50-266.

5. Were the Antiquitates of Varro (116-27 B.c.) excerpted at length by Pliny extant, Pliny's importance for this study might pale in comparison. Although Pliny wrote after Virgil and Ovid, much of the material he codifies might have been known to these poets through Herodotus, Varro, and others. 
The artistic preeminence of these labyrinths derives partly from the excellent artwork they contain but chiefly from their immensely complicated structure. Oldest and most illustrious of all was the Egyptian maze, which Pliny describes as still extant. This impressive monument inspired Daedalus, whose Cretan labyrinth, a markedly inferior copy, included only a hundredth of the "passages that wind, advance and retreat in a bewilderingly intricate manner [quae itinerum ambages occursusque ac recursus inexplicabiles]" in the Egyptian exemplar. 6 Not surprisingly, Pliny finds it impossible to describe precisely the groundplan of this complex building with its winding passages, vast halls, and temples. ${ }^{7}$ The "bewildering maze of passages [viarum illum inexplicabilem errorem]" consists of several storeys above and below ground crammed full of columns, galleries, porches, and statues of gods, kings, and monsters. Most of the edifice is dark and noisy, for the passages are vaulted with marble and arranged so that "when the doors open there is a terrifying rumble of thunder within."

As if the maze were not already hard enough to visualize, Pliny reminds his contemporaries that this labyrinth bears no resemblance to the mazes they know: "It is not just a narrow strip of ground comprising many miles of 'walks' or 'rides,' such as we see exemplified in our tessellated floors or in the ceremonial game played by our boys in the Campus Martius, but doors are let into the walls at frequent intervals to suggest deceptively the way ahead and to force the visitor to go back upon the very same tracks that he has already followed in his wanderings [sed crebris foribus inditis ad fallendos occursus redeundumque in errores eosdem]." According to Pliny, then, the Egyptian labyrinth is quite unlike the unicursal, two-dimensional mosaic labyrinths surviving in some abundance

6. The Egyptian labyrinth was probably the mortuary temple of Amenemhet III at Hawara: see note $d$ on pp. 68-69 of the Pliny text; Matthews, pp. 12-16; and Kern, chap. 3, who suggests that, to the ancients, "labyrinth" signifies chiefly "admirable stone building."

"Apollodorus" (date uncertain), whose concerns are chiefly literary, and Pausanias (fl. 150 A.D.), describing Greece, are the only historical-geographical writers to pay much heed to the vanished Cretan monument that modern readers think of as the maze. Naming Daedalus as the architect, "Apollodorus" describes the Cretan labyrinth, with what may be a tag from a lost play of Sophocles, as a chamber "that with its tangled windings perplexed the outward way"-The Library 3.4, trans. Sir James George Frazer, LCL, 2 vols. (London: William Heinemann, 1921). For Pausanias, who apparently assumes that no description of the labyrinth is needed, see Description of Greece, trans. W. H. S. Jones, LCL, 4 vols. (Cambridge: Harvard University Press, 1959), Attica, 27.10. Strabo (63 B.C.-19 A.D.) mentions the Cretan labyrinth in connection with Minos (10.4.8) but does not describe it; he also notes "the caverns, and the labyrinths built in them, which are called Cyclopeian" near Nauplia (8.6.1). The association of mazes with caves occurs periodically in classical and medieval literature.

7. Other authors mention twelve courts and three thousand rooms (Herodotus) or one thousand houses and twelve palaces (Pomponius Mela, first century A.D.), further testimony to the vastness of the Egyptian labyrinth, and all descriptions agree on the innumerable enclosed curving passages, colonnades, and subterranean tunnels that make the labyrinth so dazzlingly complex in layout. 
from the classical period: these have no false turnings and offer no real possibility of getting lost but instead involve repeated turns and twists that infallibly guide the eye, finger, or footstep to the center (see plate 3). ${ }^{8}$ Nor is it like the lusus Troiae, that horse-ballet/tournament ritual with interlocking paths so popular in imperial Rome, of which more later. Instead, the Egyptian building is a multicursal architectural construction, multistoreyed, full of twisting corridors and doors and halls, whose darkness and myriad passages would make a stranger become irretrievably lost.

As there is unanimity on the magnificence of the ancient labyrinths as works of art, so too there is agreement on the complexity of their floorplans. But some dissension exists concerning the exact nature of that complexity. Pliny explicitly contrasts the more complicated multicursal form of the Egyptian (and, by extension, the Cretan) labyrinth with the unicursal design of mosaic floors, and early authorities agree that one could easily get lost in three-dimensional labyrinths. But an intriguing hint of confusion between unicursal and multicursal designs may be found in Pomponius Mela's account of the Egyptian building, which has "one descent down to it, but inside has almost countless routes which are doubtful [ancipites] because of the many deviations, which turn this way and that with a continuous curvature, and entrances that are of ten dead ends [revocatis]. The labyrinth is entangled by these routes, which impose one circle on another; by their bending, which constantly returns as far as it had progressed; and by a wandering which is extensive but which can nevertheless be unraveled." Mela seems to want it both ways: the building's many paths, multiple internal entrances, and dead ends are sure signs of an inextricable, multicursal maze, yet at the same time he apparently envisages a single entry to the whole maze and a continuously curving path, winding back and forth, that eventually leads to extrication-a design that would resemble the unicursal pattern. Perhaps Mela simply blurred Pliny's careful formal distinction in trying to describe the maze's groundplan in words; but this uncertainty-or is it a tendency to see the maze as both unicursal and multicursal?-is characteristic of much classical and medieval thought and may reflect a reconciliation of the unicursal model familiar in art with the multicursal model of literature. We return to this subject in the next chapter.

If the great labyrinths are structurally so complex that they confuse wanderers and writers alike, why so? What is the reason for such elaborate structure? The historian-geographers do not tell us directly, but they permit informed guesses. One reason may be purely aesthetic. Labyrinths are insurpassable paragons of architectural skill, and many writ-

8. For these pavements, see Matthews, chap. 8; Santarcangeli, chap. 9; Kern, chap. 6; and chap. 2 below. 
ers make a point of preserving the names of the architects: the mazemaker Daedalus's fame is widespread, and Pliny mentions the restorer of the Egyptian maze and the Lemnian architects while noting with chagrin that the forgotten designer (artifex) of the Etruscan maze deserved greater praise than its vainglorious sponsor, Lars Porsenna. As the pinnacles of human art, labyrinths might well be intensely complicated and artificial: the more elaborate, the more beautiful. As highly important buildings, too, labyrinths might fitly be intricate. True, the precise functions of ancient mazes were open to debate. According to some sources, the Egyptian and Etruscan labyrinths were monuments to their commissioners, who were either entombed within or simply memorialized. Others suggest that the Egyptian labyrinth was, or included, a great palace. ${ }^{9}$ As witness to the preeminence of patrons and architects alike, an ornate and intricate structure, "greater than all human works" according to Herodotus, is justifiable on purely artistic grounds. So too if, as Pliny reports, the labyrinth was a temple to the Sun-god and contained precincts for all the Egyptian gods. ${ }^{10}$ The religious and commemorative functions of ancient labyrinths suggest another reason for complex structure: as protection, to impede access to sacred places or to deny a quick escape to thieves or the sacrilegious. We will see variations on many of these putative functions of the Egyptian labyrinth later: the complex architectural splendor of a labyrinth makes both a compelling propagandistic statement honoring architect or commissioner and an effective defense against intrusion. Form follows function.

Although there may be ample aesthetic and pragmatic justification for the intricacies of the Egyptian, Lemnian, and Etruscan mazes (the Cretan labyrinth presents a different problem, as we shall see), the effect of such buildings is curiously double, enforcing dismay as well as delight. Pliny notes that visitors to the Egyptian labyrinth are "exhausted with walking" even before reaching "the bewildering maze of passages," and he cites Varro's description of the pyramid-bedecked "tangled labyrinth [labyrinthum inextricabile]" in Etruria, "which no one must enter without a ball of thread if he is to find his way out." Even with a guide, Herodotus experienced "countless marvelings" at the Egyptian maze's "extreme

9. For the labyrinth as tomb see Pliny, who suggests numerous reasons for the Egyptian maze's construction; Diodorus (1.66); Herodotus (who claims that twelve cooperative Egyptian kings created a common monument to their glory); and Strabo. For the labyrinth as palace see Demoteles (cited by Pliny); Herodotus; and Strabo. We know nothing about the function of the labyrinth on Lemnos.

10. Strabo cites another use for the Egyptian labyrinth: citizens administered justice there in important cases and sacrificed to the gods. Why these functions require so complex a building is not immediately obvious unless ancient law was as labyrinthine as Victorian law seemed to the Dickens of Bleak House. In any case, the connection between judgment and labyrinth, reflected in the association of the Cretan labyrinth with Minos the Law-giver, recurs in Dante's Divine Comedy, Chaucer's House of Fame, and the anonymous Assembly of Ladies, to be discussed later. 
complication," and he never penetrated the dangerous lower chambers inhabited by dead kings and sacred crocodiles. Strabo comments that "no stranger can find his way either into any court or out of it without a guide." In short, the complexity of these mazes renders them baffling to strangers within, however admirable the buildings may be from a purely artistic point of view. For historical-geographical writers, the labyrinth is thus simultaneously a stupendous work of art and an image of confusion: objectively, as artifact, it is a magnificent design; subjectively, as experience, a potential chamber of horrors. Because of its structural complexities, its vast array of halls, crypts, corridors, and winding paths, its "ambages," "anfractus," and "errores," the labyrinth is difficult to enter and to leave ("inexplicabilis," "inextricabilis"). And the legacy of this legendary complexity? As later metaphorical uses of "labyrinth" suggest, any complicated building with many chambers and corridors is potentially labyrinthine; any building or mental process dif ficult to penetrate or escape without a guide is a kind of maze; and the most authentic mazes, at least in literature, are multicursal, allowing wrong choice and, consequently, perpetual entrapment.

Some solutions to the maze's entanglements are implied or stated by ancient writers. Visitors may have a guide or a ball of thread; habitués may learn the labyrinth's intricacies in time. Strabo recommends changing one's point of view: from the top of the building, one can see its design more clearly. This is the earliest reference I know to the important idea that the maze's ability to bewilder depends on one's perspective, in that a privileged view from above may (like the diagrammatic mosaics) reveal a clearly articulated groundplan, whereas anyone inside the structure will be reduced to confusion. Once you learn the maze or see the labyrinth whole, then, elaborate chaos is transformed into pattern. This potential conversion of the labyrinth from confusion to order, from involved process to brilliant product, is a common theme in later writings, particularly those dealing with metaphorical mazes of epistemology or of literary texts.

What are the main features of the historical-geographical labyrinth that inform later literal and metaphorical treatments of the image? First, the labyrinth is a miraculous work of art, a masterpiece of masterarchitects, a fitting monument to the fame of designer and commissioner, a worthy temple or palace for gods or men. Second, the very intricacy that makes the maze an architectural wonder as an artifact renders it almost incomprehensible as a process experienced by the disoriented wanderer. There is thus a pronounced tension between the maze as complex order and the maze as chaos. This characteristic ambiguity and convertibility of the maze, perceived as an inextricable prison one moment and as great art the next, is of ten encountered in later labyrinthine art and metaphor. In short, the maze is an embodiment of 
contraries-art and chaos, comprehensible artifact and inexplicable experience, pleasure and terror. Other attributes of the maze important to later writers appear in these early descriptions. Darkness and noise, concomitants of chaos, recur in later labyrinths. So too with some of the maze's functions: as a tomb (later associations will be with death or with hell); as an elaborate memorial to sponsor or builder; as a place of worship or judgment; as a place requiring a guide; as a fitting habitat for monsters, whether painted (as in Pliny) or real (as in Herodotus); as an image of deceptiveness; and as a building intricately designed to protect from intruders what lies within. All these connotations of the labyrinth's structure, effect, attributes, and functions reappear in later works, perhaps most systematically in Chaucer's House of Fame.

Because the Egyptian maze was the most fully described of the four ancient labyrinths, later physical descriptions of labyrinths as buildings, as real places, are frequently based on the Egyptian monument, the Cretan maze having been dismissed by Pliny as analogous, inf erior, and derivative. ${ }^{11}$ In the twentieth century, labyrinthine speculations can be based on Sir Arthur Evans's archaeological research, which uncovered an elaborate palace at Knossos built between 1800 and 1400 B.C. and profusely decorated with meander patterns and double axes (the labrys) related to the Minoan bull cult. ${ }^{12}$ But this Cretan palace, destroyed in 1400 B.C., was unknown to classical and medieval writers and had no direct impact on literature or the visual arts, unless perhaps its very disappearance permitted imaginative legends about the Cretan maze to thrive unchecked by constricting reality.

These legends, the stuff of fiction rather than the "facts" we have just examined, were most authoritatively transmitted to later periods by Virgil's Aeneid and Ovid's Metamorphoses and Heroides 10, which became standard school texts in later classical and medieval times. The poems as-

11. Some authors, Cedrenus and Claudian among them, thought the real Cretan labyrinth was a system of caves at Gortyna instead of a building at Knossos: see Matthews, p. 23; Charles Daremberg, Dictionnaire des antiquités (Graz: Akademische Drùck-u. Verlagsanstalt, 1969), s.v. labyrinthus. Kern (chap. 2) discusses the tradition of the labyrinth as a cave but assumes that no Cretan labyrinth structure ever existed; instead, the Cretan labyrinth design, so common on Hellenistic coins, describes the choreographic pattern of a labyrinth dance signif ying the end of Athenian tribute to Crete, an initiation rite, or the role of Theseus as true founder of the city of Athens. Perhaps; but I am concerned neither with speculation on the unknowable ultimate origins of pattern and legend nor with the maze's prehistoric religious or other functions but rather with documentable classical and medieval interpretations of the labyrinth.

12. See Arthur John Evans, The Palace of Minos at Knossos, 4 vols. (London: Macmillan, 1921 ); for a brief summary, see Matthews, chap. 6 . One fresco of meander patterns constitutes the only early example of a multicursal maze, although there is no clear entry and no center: see Evans, fig. 256. For further anthropological-archaeological twentiethcentury comments on Egyptian and Cretan labyrinths, see Knight, Cumaean Gates; Borgeaud, "The Open Entry"; Clark, Catabasis; Deedes, "The Labyrinth"; Santarcangeli, chaps. 4 and 5 ; and Kern, chaps. 2 and 3. 
sume prior knowledge of the Cretan myth, though it is not clear whence that knowledge would normally have come; for some readers, it might have been supplied by commentators such as Servius (b. ca. 350 A.D.). ${ }^{13}$ Most of the explicit references to the Cretan legend in Virgil and Ovid (Virgil's description of the lusus Troiae is an exception) stress the story of the maze, not its structure; their interest lies more in the characters whose destinies are touched by the labyrinth than in the grand artifact itself. Hence while the labyrinth continues to connote artistry, if only because it was built by the great architect Daedalus, negative connotations of confusion and imprisonment come increasingly to the fore, and the complex process of the labyrinth overshadows the idea of the labyrinth as complex product. If historical-geographical writers, delighted by labyrinthine artistry, provide ancient roots for metaphorical interpretations of the labyrinth in bono, classical poets tend rather to anticipate the labyrinth in malo.

Virgil uses the image of the labyrinth far more richly than either Pliny or Ovid. In Chapter 8, I show how the labyrinth functions as a central image in the Aeneid as a whole; here, however, I discuss only the two passages that refer explicitly to the labyrinth and thus help establish its potential metaphorical significance in later ages.

The first passage (Aeneid $5 \cdot 545^{-603}$ ) is an exception to the general rule that classical poetry stresses the plot and characters of the Cretan myth rather than the labyrinth as artifact, and as an exception it provides a useful transition between the historian-geographers and the poets. Here Virgil describes the culmination of Anchises' funeral games in Sicily, where the more timorous Trojans will remain to build a new Troy. Aeneas summons his young son Ascanius, who has devised an elaborate course for his fellows on horseback ("cursus ... instruxit equorum," 5.549) to honor Anchises. Three mounted troops of a dozen boys each are led forth by little Priam, Atys, and Ascanius, galloping in intricate patterns, charging and withdrawing, "interweaving circle into circle in alternation" (5.584/768), now feigning battle, now peace. ${ }^{14}$ To suggest the entwined complexity of this ritual, Virgil uses two similes:

\footnotetext{
ut quondam Creta fertur Labyrinthus in alta parietibus textum caecis iter ancipitemque mille viis habuisse dolum, qua signa sequendi
}

13. Readers may wish to refer to my summary of the story at the end of the Introduction.

14. Although hereafter I quote Fairclough's archaic but literal prose LCL translation of the Aeneid, giving parenthetical references to Latin line numbers, here I quote Allen Mandelbaum, The Aeneid of Virgil (Berkeley: University of Calif ornia Press, 1982), 1. 768. Alternative interpretations in square brackets are my own, and, along with comments on various shades of meaning, are based on Lewis and Short, checked against the Oxford Latin Dictionary. 
falleret indeprensus et inremeabilis error:

haud alio Teucrum nati vestigia cursu

impediunt texuntque fugas et proelia ludo,

delphinum similes, qui per maria umida nando

Carpathium Libycumque secant luduntque per undas. $\quad\left(5 \cdot 5^{88-595)}\right.$

As of old in high Crete 'tis said the Labyrinth held a path woven with blind walls, and a bewildering [double] work of craft with a thousand ways, where the tokens of the course were confused by the indiscoverable and irretraceable maze: even in such a course do the Trojan children entangle their steps, weaving in sport their flight and conflict, like dolphins that, swimming through the wet main, cleave the Carpathian or Libyan seas and play amid the waves.

Virgil goes on to say that Ascanius revived the game when he encircled Alba Longa with walls and that it has come down to Virgil's day "as an ancestral observance" (5.601); in Augustan times, he says, "the boys are called Troy and the troop Trojan" (5.602).

The lusus Troiae or Trojan Ride was well known in Rome. Noble youths staged these complex equestrian ballet-tournaments at least as early as Sulla's time (ca. 8o в.c.); the rides contributed to the festivities at Julius Caesar's triumph in 46 B.c., Augustus favored them, and Nero performed in them. ${ }^{15}$ Of course Virgil is complimenting Augustus by tracing the origin of the lusus Troiae to Aeneas and Ascanius, but it is nevertheless possible that the game is indeed ancient and that tradition informed Virgil's linking of the game with the labyrinth: an Etruscan wine-pitcher dating from the seventh or sixth century B.c. shows two horsemen riding out of a diagrammatic unicursal labyrinth with "truia" inscribed in one of its coils (see plate 2). The meaning of truia is much debated: possibly an Etruscan word for "Troy," it is also, more hypothetically, an obscure Latin word meaning "dancing-floor" or "arena." 16 The design clearly establishes a connection between rituals on horseback

15. See Suetonius, The Lives of the Caesars 1.43 and 6.7; Matthews, chap. 18; and John L. Heller, "Labyrinth or Troy Town?" CJ, $4^{2}$ (1946), 123-139, which discusses attempts to reconstruct the game. For an extensive bibliography of Troy-game literature, see August Friedrich von Pauly, Realencyclopädie der classischen Altertumswissenschaft, ed. Georg Wissowa (Stuttgart: Alfred Drückenmuller Verlag, 1956), Suppl. 8, cols. 9o4-905. Kern (chap. 5) cites the games at the founding of Alba Longa to support his hypothesis that labyrinth dances, on or of $f$ horseback, were practiced at the founding of Roman cities as a magically protective act delimiting a privileged space; he also sees the game as a male initiation rite. I see no clear evidence for either conjecture, although the youth of the riders offers some, if not sufficient, support for the initiation theory.

16. For the Tragliatella pitcher, see G. Q. Giglioli, "L'oinochoe de Tragliatella," Studi Etruschi, 3 (1929), 111-159; Kern, pp. 87-91; and Heller, "Labyrinth or Troy Town." For the etymology, see Heller's article and his "A Labyrinth from Pylos?" American Journal of Archaeology, ser. 2, 65 (1961), 57-62. The significance of the couples copulating rather ingeniously behind the labyrinth is puzzling: are mazes linked with lust this early? 


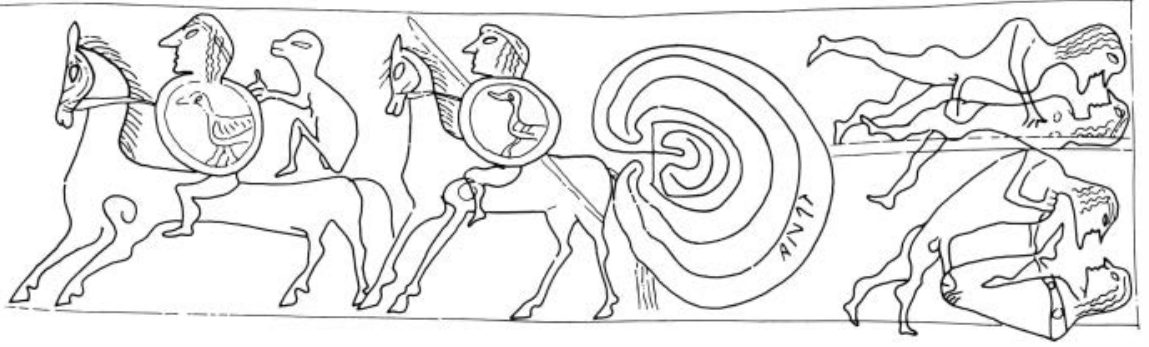

2. Horsemen, Cretan-style maze, and copulating couples from the Tragliatella wine-pitcher (Etruscan, seventh century B.C.). The inscription in the maze design reads "Truia." Drawing by Robert Ouellette after G. Mariani.

and labyrinths, so Virgil was presumably not creating his simile from thin air. Whether or not the Etruscans also anticipated his linking of such games with Troy, and I tend to agree with John L. Heller that they did, there may be a connection between the lusus Troiae of Iulus Ascanius and the abundant turf-mazes and stone circles of northern Europe of ten known as "Troy-town" or "Julian's Bower," discussed in Chapter 5. For the moment, I limit my observations to other qualities of the labyrinth that later readers might have extrapolated from Virgil's account. (This extrapolation might work two ways: from the brief description of the maze itself, or by analogy from the description of the labyrinthine Trojan ride.)

Several aspects of the maze in Book 5 can be mentioned very briefly. Virgil, like the historian-geographers, connects the maze with fame and memory, at least by analogy, in associating labyrinthine games with the honoring of Anchises and the implied honoring, in later Roman rides, of Rome's Trojan ancestors. And Virgil here associates the labyrinth with (fairly serious) play and game, although few later writers develop the idea. Three aspects of Virgil's lusus Troiae/labyrinth simile require fuller discussion.

The comparison of the lusus Troiae to the labyrinth is based on the fact that both are complex in pattern, difficult to follow, and interwoven ("alternosque orbibus orbis / impediunt," "textum"). This complexity is partly the result of a multicursal design: if the Cretan labyrinth has its thousand ways, the lusus Troiae has at least three interlocking paths corresponding to the three troops of riders with their entangled steps. In maze and game alike, complexity derives from studied artistry: the Trojan ride, a performance of considerable intricacy, presumably required a Daedalian choreographer (Epytides? Ascanius himself?) who taught ("instruxit") the figures to performers who had to be "paratum," ready, 
probably in the sense of "rehearsed." This impression of artistry is heightened by the description of the maze itself as "ancipitem . . . dolum," a double (multicursal?) work of craft. The comparison of game to labyrinth is apt, then, because of the artistic complexity they share. ${ }^{17}$ The effect of this complexity, however, differs. In the maze, described as if experienced from within, the emphasis is on confusion and entrapment ("indeprensus et inremeabilis error"-indiscoverable and inescapable wandering). The Trojan Ride, admired from without, elicits only joy, and its participants, having committed the pattern to memory, appear to feel no confusion. Here again is the perspective-dependent paradox of the artistic labyrinth: within, at least to the untutored, all is tricky chaos; without, or to the enlightened maze-treader, all is careful pattern. This passage, like Strabo's offhand remark, might suggest to a thoughtful interpreter that labyrinths and labyrinthine art, properly absorbed and understood, viewed from the right mental or physical angle, are quite literally art of the highest order; but it might also anticipate the common late medieval reluctance to call pleasurably labyrinthine art a labyrinth in fact (see Chapter 7). The Trojan Ride is very like a labyrinth, but Virgil gives us a simile, not metaphorical equation; readers are free to limit or expand the resemblances between game and building.

A related extrapolation is that Virgil suggests the coexistence of process and product in the lusus Troiae/maze comparison. The labyrinth itself is characteristically dual, both an artifact-a work of objective craft - and a sequence of bewildering disorientations; the Trojan Ride includes not only the dynamic movements of the mounted troops but also, implicitly, the static patterns left on the sand by the horses' hooves, patterns that presumably help suggest the comparison to a labyrinth. In other words, Virgil evokes a diagrammatic pattern of the maze, which is more usually described as a building. Maze diagrams have been common since prehistoric times, and fourth-century Hellenistic coins spread the common unicursal circular design across the civilized Mediterranean; but Virgil's text is the earliest I know to envisage the two-dimensional design of a maze and link it with the three-dimensional Cretan building. His simile helps explain a problem that has bothered virtually every modern writer on the subject: how did the word labyrinthus, in classical literature almost always used for a building in which one could get lost, come to refer to the unicursal two-dimensional maze, in which one cannot get lost, found in Roman mosaics as in medieval churches and fields? Pliny shows that by his time the same word referred to both phenomena;

17. Indeed, the lusus Troiae is compared both to artificial complexity (the labyrinth) and to natural intricacy (the playf ully interwoven paths of the dolphins); analogous comparison of Daedalus's work to nature's occurs in other classical and early Christian writings. See below, on the adjective daedalus, and chap. 3 . 
and Virgil's description of the lusus Troiae, which Pliny probably had in mind, may have helped the association to develop. ${ }^{18}$

Finally, we should note the presence and implications of some terms commonly used of labyrinths, terms that isolate special qualities of the maze: the blind walls, the double woven path, the thousand ways, the inremeabilis error. Virgil uses texere twice, and later analogies between discourse and labyrinths presumably reflect their similar status as texts, things woven. ${ }^{19}$ What we do not find in this passage (or, for that matter, in the historian-geographers) is any overt reference to the Cretan labyrinth's salacious history or its chief mythological function: to conceal Pasiphae's shameful progeny and to imprison anyone who ventures within. Perhaps such ref erences would be out of place in the description of an ancient, noble, ongoing Roman ritual. Nevertheless, there areespecially for postclassical readers-oblique glances at the negative face of the Cretan maze in such words as anceps ("double," but also "dangerous, hazardous, perilous"), dolus ("artifice; deception"), inremeabilis (from which, like hell or death, one cannot return), and error ("wandering, going astray"- physically, morally, or intellectually). But despite the latent seaminess of lexis and labyrinth alike, in Book 5 Virgil presents a labyrinth quite literally reformed: a complex artistic process and product, a conversion of the ancient Cretan prison to a playful, solemn, and forward-looking Roman ritual, very much a labyrinth in bono.

The history of the labyrinth in malo-or at least partly in malo-is outlined in Book 6.1-105, when Aeneas lands in Italy at Cumae. After passing through the groves of Trivia (Diana of the Crossroads), he comes to the temple of Apollo built by Daedalus, who there dedicated his wings to the god after his ill-fated flight from Crete. There too Daedalus sculpted door panels illustrating the Cretan legend: the death of Androgeos, the Athenian tribute to Crete, and Crete itself.

hic crudelis amor tauri suppostaque furto

Pasiphae mixtumque genus prolesque biformis

Minotaurus inest, Veneris monumenta nefandae;

hic labor ille domus et inextricabilis error;

18. Pliny's comment, quoted earlier, can be read several ways. He differentiates the Egyptian labyrinth from familiar Roman ones in that the Egyptian maze is multicursal and deceptive, on the one hand, and three-dimensional, on the other. He does not clearly identify the Trojan Ride-presented by Virgil as multicursal-as either multi- or unicursal: the main point of the passage is to contrast mosaic mazes with the Egyptian building, and the Ride seems to be brought in as a complex ceremony that uses mosaic-like twodimensional floor-markings as a guide to the horsemen, an ancient analogy to the modern taping of stage floors to orient dancers.

19. The usage of textus to refer to a literary text, common in medieval Latin, occurs as early as Quintillian: see Lewis and Short and the Oxford Latin Dictionary, s.v. textum/textus, and Brian Stock, "Medieval Literacy, Linguistic Theory, and Social Organization," NLH, 6 $(1984-85), 13^{-29}$, here 21. 
magnum reginae sed enim miseratus amorem Daedalus ipse dolos tecti ambagesque resolvit, caeca regens filo vestigia. $(6.24-30)$

Here is the cruel love of the bull, Pasiphae craftily mated, and the mongrel breed of the twiformed of fspring, record [memorial, tomb] of monstrous [impious] love; there that house of toil [or: the workmanship of the house], a maze [a wandering, a going astray] inextricable; but lo! Daedalus, pitying the princess' great love, himself unwound the deceptive tangle of the palace, guiding blind feet with the thread.

Aeneas wants to study (perlegere) the relief, but the Sibyl hurries him on to her oracular and rather labyrinthine cavern with "its hundred entrances, hundred doors, whence rush as many voices" (6.43-44). Later Aeneas proceeds through labyrinthine quests for the golden bough and for his father Anchises in Hades: the maze at the temple doors is a significant clue to the book's action.

In Chapter 8, I treat the labyrinths of the Aeneid more fully, but several points claim attention now. If the labyrinth manifested complex artistry in Book 5, so too in Book 6, but the emphasis shifts from the labyrinth itself to its human context, its story. Virgil hints, albeit elliptically, why the labyrinth was built: to conceal the doubly named, double-natured Minotaur, and to bewilder the Athenians sent as its fodder. Inextricable error, deceptive windings, and dead ends are no longer mere aspects of artistic design but rather necessary impediments in a building whose multicursal form follows a sinister function; the Egyptian palace has become a prison, and the celebratory lusus, public ritual enactment of adult life, is replaced by a grim private ritual of death. The association of the labyrinth with fame, familiar from the historian-geographers and Aeneid 5, remains, but it shades into infamy: the labyrinth, like the Minotaur, is a monument to impious lust-indeed, to insane bestialityand is implicated in Theseus's later betrayal of the loving Ariadne. The death implicit in the memorial functions of the Egyptian and Etruscan mazes and in Anchises' funeral ballet here becomes violent, unnatural. The literary ground is fully prepared for later metaphorical identification of the labyrinth in malo with destructive love, seductive treachery, sin, death.

So unspeakable are the labyrinth's causes and contents that its very name remains unspoken; we read simply "hic labor ille domus et inextricabilis error," yet the context and the presence of several key wordslabor, inextricabilis error, dolus, ambages - make it clear that this is indeed the labyrinth. Few later descriptions of the maze, including Ovid's and Pliny's, do not include these words, which describe some of the most definitive characteristics of the labyrinth and shape its metaphorical potential. As many writers follow Virgil in punning on labor and labyrinthus, 
so too many, Ovid and Prudentius among them, apparently assume their readers will understand "maze" when enough qualities and key words of the maze have been mentioned, even if the word "labyrinth" occurs nowhere in the text.

Yet labor is itself ambiguous: as a noun, it can refer to arduous process - toil, hardship, suffering-but it can also refer, far more optimistically, to a product, the accomplished work of an artist. ${ }^{20}$ And despite the full weight that Virgil gives here to the horrors of the maze, it is Daedalus, among the maze's cast of characters, who dominates the passage as artist and father, escaping from the labyrinth he himself created to found a temple to Apollo, god of poets and artists, and ornamenting that vast new building with an image of the old labyrinth and a scene in which he offers a solution to its entanglements-a ball of thread-that he himself could not use once the maze had become his own prison. The art of the old labyrinth may have been in the service of evil, and the art of the new labyrinth and temple may carry seeds of failure and frustration (the artist cannot depict the death of his son Icarus, and he seems almost entrapped in the self-reflexive creation of new artistic mazes). Yet through his craftiness he has twice solved the inextricable labyrinth-by the aide-mémoire of a thread and by flight-and that flight in itself suggests the double perspective on mazes (the experience within, the view from without) we have met before. He has created the original labyrinth by art, and he has, in a sense, reduced its very real dangers to art in the service of Apollo. That reduction admittedly poses a different sort of danger to pius Aeneas, erstwhile wanderer in mazes of impious love; he must be chastened when he wishes to study the doors at length, to remain, after so many books of errores, in one labyrinth when he ought to be proceeding through others that lie ahead. Art, even difficult labyrinthine art, is no substitute for life and duty. Nevertheless, Virgil's emphasis on the role of Daedalus as artist necessarily presents the labyrinth as an artistic triumph as well as a house of suffering. The labyrinth's duality as art and as (moral as well as physical) confusion is restated.

The Daedalus-artist-labyrinth-Apollo conjunction here may authorize later associations of Daedalian art and labyrinths with poetry or rhetoric. The link between Daedalus and craftsmanship in general was commonplace, as use of the adjective daedalus ("artificial, skillful"; "intricately worked") makes clear. Thus Virgil praises "daedala Circe" (Aeneid 7.282), whose perverse brilliance in animal husbandry rivaled that of Daedalus (helping Pasiphae) when she mated immortal stallions with mortal mares, and in Georgics 4.179 the bees craftily construct "daedala tecta," labyrinthine hives. Of ten it is Nature who is Daedalian (Lucretius, De natura rerum 1.7 and 5.234). However, the connections between

20. Thus Lewis and Short interpret labor in this passage. 
Daedalus and poetry are suggested by more writers than Virgil. Lucretius speaks of "verborum daedala lingua" (4.549), "the tongue, cunning crafter of words." Sextus Pompeius Festus, epitomizing the Augustan Verrius Flaccus, derives the adjective from the Greek daidallein, "to vary"; a skillful varying of words is, after all, the essence of poetry, and surely that is what the verbal pyrotechnician Ausonius (fourth century A.D.) has in mind in coining "logodaedalia," a term he uses pejoratively despite his own exceedingly ornate practice. ${ }^{21}$ Himself a cunning crafter of words, Virgil is also skilled at variations on the Daedalian art of the labyrinth, an image he transforms creatively even as he tames it, Romanizes it. Seeing its dangers as well as its grand potential, he shows Ascanius turning its complexity to a noble game of the warrior's life and Aeneas extricating himself from its moral temptations and delaying byways to achieve his goal. For Virgil, passage through the labyrinth can be a (reversible) voyage from confusion to clarity, and so the positive and negative connotations of the maze, its objective artistry and its subjective disorder, are held in a delicate balance.

What Virgil handled allusively and suggestively, his younger contemporary Ovid treats in the Metamorphoses and the Heroides at greater length and more literally; after all, Virgil subordinates the Cretan myth to a greater purpose, the epic journey of Aeneas, whereas Ovid's subject is myth itself, recounted with considerable detail, fanciful ingenuity, and charming dramatic invention. The Ovidian focus on the characters associated with the labyrinth rather than on the labyrinth itself domesticates the maze, which becomes more important simply as a setting and less resonant as an image than in Virgil. The dual status of the maze as artistic marvel and moral emblem remains prominent, however, at least in the Metamorphoses, to which we turn first.

Set in that large section of the Metamorphoses exemplifying what Brooks Otis calls "the pathos of love," 22 the Cretan interlude offers a comprehensive version of the myth, including Minos's encounter with Scylla, Pasiphae's conception of the Minotaur, its imprisonment in the labyrinth built by Daedalus to hide Minos's shame, its death at the hands of Theseus, his abandonment of Ariadne, the flight of Daedalus and Icarus from Crete, Icarus's death, and-to point the poetic justice of Daedalus's loss-the story of the master architect's murder of his clever

21. See Festus, De verborum significatione . . cum Pauli Epitome, ed. Carl O. Mueller (Leipzig: Libraria Weidmann, 1839), s.v. daedalam; and Ausonius, Technopaegnion 14.1.

The location of Virgil's sculpted maze may also help establish an association between labyrinth and poetry in later years: the temple lies near the groves of Trivia, the word itself suggesting the crossroads inevitable in multicursal mazes and, for medieval commentators, the academic trivium, which comes to have its own mazy associations. See Pseudo-Bernard Silvester, J\&J, pp. 30-31.

22. Otis, Ovid as an Epic Poet (Cambridge: Cambridge University Press, 1966), chaps. 6 and 7 . 
nephew, whose metamorphosis into a partridge provides humorously far-fetched justification for the inclusion of the whole history in Ovid's poem. That Ovid's audience, like Virgil's, knew this history intimately is clear from what Ovid omits even in his expansive retelling of the myth: we are not told, for instance, that Athens sent its young men to Crete as tribute for the death of Minos' son Androgeos, or that Daedalus helped Pasiphae consummate her lust for the bull, nor is the famous labyrinth ever called by its proper name, all points explained in great detail by medieval Ovidian commentators.

What Ovid does tell us about the labyrinth, that circumambulation named only by circumlocutions, is worth quoting in full for its tremendous importance in later literature. ${ }^{23}$ Worried that his wife's foul lust was visible to all in the form of the "monstrum biforme," the Minotaur,

destinat hunc Minos thalamo removere pudorem
multiplicique domo caecisque includere tectis.
Daedalus ingenio fabrae celeberrimus artis
ponit opus turbatque notas et lumina flexu
ducit in errorem variarum ambage viarum.
non secus ac liquidus Phrygius Maeandrus in arvis
ludit et ambiguo lapsu refluitque fluitque
occurrensque sibi venturas aspicit undas
et nunc ad fontes, nunc ad mare versus apertum
incertas exercet aquas, ita Daedalus implet
innumeras errore vias vixque ipse reverti
ad limen potuit: tanta est fallacia tecti.
Quo postquam geminam tauri iuvenisque figuram
clausit, et Actaeo bis pastum sanguine monstrum
tertia sors annis domuit repetita novenis,
utque ope virginea nullis iterata priorum
ianua dif ficilis filo est inventa relecto,
protinus Aegides rapta Minoide Diam
vela dedit. . . (8.157-175)

Minos planned to remove this shame from his house and hide it away in a labyrinthine enclosure [lit.: many-folded house] with blind passages. Daedalus, a man famed for his skill in the builder's art, planned and performed the work. He confused the usual passages [or: confused the signs that might provide orientation] and deceived the eye by a conflicting maze of divers winding paths [or: led one's eyes into error by the winding twists of the various paths]. Just as the watery Maeander plays in the Phrygian fields, flows back and forth in doubtful course and, turning back on itself, beholds its own waves coming on their way, and sends its uncertain waters now towards their source and now towards the open sea: so Daedalus made those

23. As Otis notes, the "Metamorphoses was, more than any other work, the medium by which classical myth was known and understood"-Ovid as an Epic Poet, p. 343. 
innumerable winding passages, and was himself scarce able to find his way back to the place of entry, so deceptive was the enclosure he had built.

In this labyrinth [lit.: in which] Minos shut up the monster of the bullman form and twice he fed him on Athenian blood; but the third tribute, demanded after each nine years, brought the creature's overthrow. And when, by the virgin Ariadne's help, the difficult entrance, which no former adventurer had ever reached again, was found by winding up the thread, straightway the son of Aegeus, taking Minos's daughter, spread his sails for Dia.

Many points here were noted, adapted, embroidered, and sometimes rationalized by later writers. First, Ovid's account, perhaps even more than Virgil's, provides the raw material for a reading of the labyrinth in malo. As in the Cumaean sculpture, so here the labyrinth is functionally a prison; to that end were its inextricable complexities designed. Both the quoted lines and their larger Ovidian context, involving Scylla's passion for Minos and Ariadne's ill-fated elopement, emphasize the shamefulness of lust, for whose most outrageous product the maze was crafted. The fact that Minos the law-giver ordered the imprisonment of the Minotaur supports later associations of the maze with just imprisonment. ${ }^{24}$ These points may well have influenced later redactors of a narrowly moral bent to consider the labyrinth a prison for monstrous cupidity, an image of sin, or hell itself, even though such interpretations belie Ovid's typically deft presentation (and diminution) of the labyrinth as a private lunatic asylum commissioned by a cuckolded king to prevent personal embarrassment.

If Ovid fuels the interpretation of the labyrinth in malo, however, he also accentuates the artistry of the maze, not so much in describing it as in remarks about Daedalus the master builder and inventor who, despite his dubious morals, comes fairly to fame as the greatest of artists, his many-folded house the supreme achievement of human architecture, however greatly Pliny might have preferred the anonymous Egyptian architects. $^{25}$ But Ovid also presents Daedalus almost as a trickster who

24. Minos was proverbially a law-giver in the ancient world: see Plato, Laws 1.63oD; Apology 41A; Gorgias 524A. For Strabo, the Egyptian labyrinth was also a place of judgment. Presumably the (Pythagorean) choice between paths, one's final location in Hades, and the act of judgment after death were of ten interconnected, as in the Gorgias.

25. Daedalus's reputation is incorporated into the Latin language itself: as we have seen, "daedalus" comes to mean "skillful, artificial," and the man himself is glossed repeatedly as the greatest artif ex, even a figura for God: see Fausto Ghisalberti, "L'Ovidius Moralizatus di Pierre Bersuire," Studj Romanzi, 23 (1933), 1 29-130, and Ovide moralisé en prose, ed. C. de Boer, Verhandelingen der Koninklijke Akademie, 61 (1954), p. 229. In the classical period Daedalus was famed for having created moving statues (see Plato, Meno $97 \mathrm{D}$ ) as well as labyrinth and wings, and in the Euthyphro $\left(\begin{array}{ll}1 & \mathrm{~B}-\mathrm{D})\end{array}\right)$ Socrates himself jokingly claims descent from Daedalus. Diodorus Siculus reports that Daedalus was so great an artist that the Egyptians worshiped him as a god (1.97). Yet his work was not always honored in classical times: as his masterpiece, the maze, has a dual potential, so too does its architect. Plato 
outwits himself: the remarkable ability to alter nature through art (8.188-189) leads to the death of his son, and as for his mazy masterpiece, we learn that even Daedalus could scarcely retread the ambiguous corridors of his own construction. While in a sense this comment undercuts Daedalus's stature-he becomes an absent-minded prof essor of architecture rather than the tragic figure of the Aeneid-it also suggests the provocative possibilities of the complex maze as a symbol of the deceptive trickiness of difficult art. The ingenious planner comprehended his creation as artifact, but he was almost thwarted by the maze as process. Later uses of the maze to signify difficult art - art that loses its viewers or readers because of its devastating complexity - may well be indebted to Ovid, whose story of the baffling labyrinth that bewilders its own creator was so well known. Here, as in later variations on this theme, the maze's convertibility works both ways: from disorder to order and sometimes, treacherously, back again.

The Metamorphoses highlights many qualities of the labyrinth found in Pliny and Virgil: the complex artistry of the building, its ability to entrap, its multicursal winding ways, its deceptive nature, its darkness ("caeca tecta"), and the need for a guide, a perfect architectural memory, or wings to get out. The maze's duality as artistic order and physical confusion survives in Ovid, and yet the weight of context and lexis (ambages, ambiguus, error, variae viae) tips the balance toward confusion both physical and moral, especially given Daedalus's own difficulties with his re-

mentions that "according to the sculptors Daedalus would look a fool if he were to be born now and produce the kind of works that gave him his reputation" (Hippias Major 282A). For other writers, too, he is (merely?) an astrologer: see Palaephaetus, De non credendis historiis libellus (Antwerp: Gregorius Bontius, 1528), A6r.

Martianus Capella sees Daedalus as an ancestor of Geometry, who can represent the heavens on her abacus board (De nuptiis philologiae et mercurii, ed. Adolph Dick [Stuttgart: B. G. Teubner, 1969], VI.579). Commenting on this passage in the ninth century, Remigius of Auxerre takes the typical medieval view: "Daedalus, that is, every ingenious man"Commentum in martianum capellam, ed. Cora E. Lutz (Leiden: E. J. Brill, 1965), 289.1; and for Alan of Lille (ca. 1 1 16-ca. 1 202) he is the master builder (Anticlaudianus 2.352). Benvenuto da Imola (fourteenth century) took a rather more jaundiced view of the matter, doubting that Daedalus or any other one person could have built the labyrinth, a subterranean work of great complexity: Comentum super Dantis Aldigherij Comoediam, ed. J. P. Lacaita, 5 vols. (Florence, 1887), 1, 387. Nevertheless, Daedalus's medieval reputation was glorious and widespread: a ninth-century architect named Winihard at St. Gall was praised for being like Daedalus in ingenuity (Hans Reinhardt, La Cathédrale de Reims [Paris: Presses Universitaires de France, 1963], p. 76); a fourteenth-century formulary from Orléans mentions a request to "the most learned of architects, worthy of being compared to Daedalus," to repair a mill, arguably a rather paltry task (Le Formulaire de Tréguier, ed. Léopold Delisle [Orléans: H. Herluison, 189o], pp. 7-8); and Daedalus seems to merge with that equally legendary and ingenious fellow Wayland, whose "house" is a labyrinth in two fourteenth- and fifteenth-century Icelandic manuscripts preserved in Copenhagen (Kern, figs. 468-469). Daedalus's less savory reputation in the English Renaissance is delineated by F. T. Flahiff, "Labyrinth: Some Notes on the Crafty Art of Daedalus," White Pelican, 3 (1973), 3-23. 
calcitrant creation. This shifting of the balance is a natural consequence of Ovid's emphasis on plot and character rather than on the labyrinth as a structure: the labyrinth is, in Book 8, to be used, built for dubious purposes, something to be experienced and escaped as quickly as possible, not something to study and admire. Thus it is hardly surprising that the labyrinth degenerates still further in Heroides 10, a letter from Ariadne to Theseus consisting entirely of the hysterical reproaches and fantasies of a wronged, self-righteous girl. ${ }^{26}$ As in the Metamorphoses and Aeneid 6, the labyrinth is not named: it is simply a "curving house" (10.71) full of "doubtful passages" (10.128), identified by its confusing attributes alone. But here its famous creator also goes unnamed, for this is no palace of artistry but a place of death (we hear exactly how Theseus kills the Minotaur, 10.101-102) and, symbolically, an emblem of lust, treachery, and deceit. Significantly, the lovelorn Ariadne, imprisoned in her voluminous passions, leads Theseus from the maze's "dubias vias" (10.128) only to find herself trapped on an island with no passage over the sea's "ambiguas vias" (10.62). The more we are invited to empathize with maze-walkers, to share a subjective perspective, the more labyrinthine confusion dominates and art recedes.

Before we turn from the story of the Cretan labyrinth, it is worth remembering that classical tellers of the myth, unlike publicists of the Egyptian maze, never thought for a moment they were writing a true history. It would hardly have been news to them that Augustine should deride "that beast the Minotaur, which was shut up in the labyrinth, from which men who entered its inextricable mazes could find no exit" and "the artificer Daedalus" as lying fables pure and simple. ${ }^{27}$ After all, Virgil himself speaks only "as rumor has it" (Aeneid 6.14). Part of the received tradition in the Middle Ages was the nonsupernatural interpretation held by Servius and others that Daedalus really arranged for the scribe Taurus to sleep with Pasiphae in his house, that Pasiphae's twins (one by Minos, one by Taurus) were the reality behind the Minotaur of mixed breeding, and that the wings Daedalus flew with were really sails, the first to be seen in the Mediterranean.28 None of this affects Daedalus's reputation for ingenuity-most redactions still credit him with building a real Cretan labyrinth-but Servius's explanation may have helped later writers decide to allegorize the domus daedali itself as a symbol of lust.

26. I follow the Latin text in Heroides and Amores, trans. Grant Showerman, LCL (London: William Heinemann, 1914).

27. De civitate Dei 18.13, trans. G. Wilson, in Whitney J. Oates, Basic Writings of Saint Augustine, 2 vols. (New York: Random House, 1948).

28. Servius Grammaticus, In Aeneidos, ed. Georg Thilo and Hermann Hagen, 2 vols. (Hildesheim: Georg Olms Verlagsbuchhandlung, 1961), 6.14. For a different but equally debunking interpretation, see William of Conches (twelfth century), Glosae in Iuvenalem, ed. Bradford Wilson (Paris: Librairie Philosophique J. Vrin, 1980), pp. 110-111. 
Such, then, are the definitive classical descriptions of the labyrinth and the associated Cretan myth, the literary witnesses known to generations of later writers both in themselves and as overlaid by numerous commentaries. This chapter has highlighted suggestive details that will later be glossed and embroidered, the many seeds of the prof use metaphorical flowerings of the image of the maze. We have considered the inherent paradox of the labyrinth: its ability to signify both complex artistic order and chaotic confusion, depending on whether it is viewed from without as a static artif act, a magnificent product of human ingenuity, or experienced from within as a bewildering process, a dynamic prison. We have seen the tricky convertibility of the maze, which can become clear to those it has confused or baffle those who, like Ovid's Daedalus, think they understand its symmetries. We have seen that an emphasis on the maze as an historically real structure is of ten associated with admiration, whereas an emphasis on the myth, with concurrent attention to the labyrinthine experiences of entangled human beings, frequently involves implicit or explicit moral judgments that anticipate later uses of the labyrinth as a symbol of something evil. There have also been hints of an intriguing problem: the difference between the literary tradition, which generally envisages a multicursal labyrinth, and the tradition of the visual arts, which establishes a unicursal pattern. The importance of this apparently awkward discrepancy is explored in the next chapter. 